\title{
Combination effect of photodynamic therapy using NPe6 with pemetrexed for human malignant pleural mesothelioma cells
}

\author{
SACHIO MAEHARA $^{1}$, JITSUO USUDA ${ }^{2}$, TAICHIRO ISHIZUMI ${ }^{1}$, SHUJI ICHINOSE $^{1}$, \\ KEISHI OHTANI $^{1}$, TATSUYA INOUE ${ }^{1}$, KENTARO IMAI ${ }^{1}$, HIDEYUKI FURUMOTO ${ }^{1}$, \\ YUJIN KUDO $^{1}$, NAOHIRO KAJIWARA ${ }^{1}$, TATSUYA OHIRA ${ }^{1}$ and NORIHIKO IKEDA ${ }^{1}$ \\ ${ }^{1}$ Department of Surgery, Tokyo Medical University, Tokyo 160-0023; \\ ${ }^{2}$ Department of Thoracic Surgery, Nippon Medical School, Tokyo 113-8603, Japan
}

Received September 9, 2014; Accepted October 17, 2014

DOI: $10.3892 /$ ijo.2014.2746

\begin{abstract}
To identify a possible new treatment modality for malignant pleural mesothelioma (MPM), we examined whether combination treatment consisting of pemetrexed chemotherapy and photodynamic therapy (PDT) using the photosensitizer NPe6, enhanced the antitumor effect in both in vitro and in vivo models. We also investigated preclinical treatment schedules. Four human malignant mesothelioma cell lines (MSTO-211H, H2052, H2452 and H28) were assayed using the WST assay after treatment with pemetrexed and NPe6-PDT. The treatment schedule for the combination treatment was examined using nude mice. Pemetrexed pre-treatment enhanced the lethal effect of NPe6-PDT in the four malignant mesothelioma cell lines, but NPe6-PDT followed by pemetrexed treatment did not enhance cell lethality in the in vitro assay. Pemetrexed pre-treatment did not enhance the intracellular accumulation of NPe6, which is one of the determinants of the antitumor effect of PDT. In nude mice injected with MSTO-211H cells and then treated using a combination of pemetrexed and NPe6-PDT $(10 \mathrm{mg} / \mathrm{kg}$ $\mathrm{NPe} 6,10 \mathrm{~J} / \mathrm{cm}^{2}$ laser irradiation), the tumor volume decreased by $50 \%$ but subsequently increased, reaching the pre-treatment value after 14 days. Pemetrexed treatment followed by NPe6-PDT resulted in an $80 \%$ reduction in the tumor size and inhibited re-growth. NPe6-PDT followed by pemetrexed treatment resulted in a $60 \%$ reduction in tumor size but did not inhibit re-growth. NPe6-PDT induced the expression of thymidylate synthase (TS), which confers resistance to pemetrexed, and NPe6-PDT followed by pemetrexed treatment did not enhance the treatment outcome in vivo. In conclusion, combination treatment, consisting of pemetrexed followed by
\end{abstract}

Correspondence to: Professor Jitsuo Usuda, Department of Thoracic Surgery, Nippon Medical School, 1-1-5 Sendagi, Bunkyo-ku, Tokyo 113-8603, Japan

E-mail: jusuda@nms.ac.jp

Key words: malignant pleural mesothelioma, photodynamic therapy, pemetrexed, combination therapy
NPe6-PDT, should be further investigated as a new treatment modality for MPM. In the future, this combination treatment may contribute to a reduction in local recurrence and a prolonged survival period in patients with MPM.

\section{Introduction}

Malignant pleural mesothelioma (MPM) is a locally aggressive disease characterized by a poor prognosis and an increasing incidence (1-4). MPM is difficult to detect at an early stage, and surgical and radiotherapeutic approaches are ineffective when used independently, because MPM spreads diffusely in the surrounding chest wall (5). No universally accepted treatment approach currently exists. An extrapleural pneumonectomy (EPP) with en bloc resection of the lung, pleura, ipsilateral diaphragm, and pericardium is one of the most invasive surgical procedures and is associated with a high risk of local recurrence $(6,7)$. Recently, adjuvant radiation therapy to the ipsilateral hemithorax after EPP has been reported to result in a dramatic reduction in local relapse and the prolonged survival of patients with early-stage disease (8). Pemetrexed, a multi-target anti-folate, exhibits activity against various tumors, but especially against MPM and non-small cell lung cancer (NSCLC), for which it is routinely used (9). Pemetrexed inhibits at least three kinds of enzymes involved in folate metabolism, and in pyrimidine and purine biosynthesis: thymidylate synthase (TS), dihydrofolate reductase (DHFR), and glycinamide ribonucleotide formyltransferase (10). Combination of pemetrexed and cisplatin has become the standard first-line regimen for MPM based on the results of a phase III trial showing that this combination improved survival compared with cisplatin treatment alone (11). However, the impacts of induction chemotherapy using pemetrexed and cisplatin, and of adjuvant hemithoracic radiation therapy after EPP for MPM remain controversial (12). Flores et al reported that patients who underwent a pleurectomy/decortication had a better survival outcome than those who underwent EPP (13).

Photodynamic therapy (PDT) consists of the use of a tumor-specific photosensitizer and laser irradiation to induce the production of reactive oxygen species in cancer cells $(14,15)$. This treatment modality is used for many 
cancers and is widely used as a treatment option for solid cancers (16-18). The use of PDT as a treatment for MPM has been investigated under both clinical and experimental conditions (19-21). Friedberg et al reported a phase I clinical trial of Foscan-mediated PDT and surgery in patients with MPM (20). They reported that Foscan-mediated PDT afforded the option of accomplishing tumor debulking using a lung-sparing pleurectom/decortication, rather than EPP. A phase III randomized trial of surgery and chemotherapy with or without intra-operative PDT using the first-generation photosensitizer Photofrin, was reported in 1997 (22). The study concluded that PDT using Photofrin did not prolong patient survival or increase local MPM control. However, we recently reported that PDT using the second-generation photosensitizer NPe6, has a strong antitumor effect against large tumors, which are unsuitable for treatment with Photofrin-PDT (23). NPe6 has a major absorption band at $664 \mathrm{~nm}$, which is longer than the Photofrin band $(630 \mathrm{~nm})$, and NPe6-PDT can affect deeper lesions. Therefore, in an attempt to establish a new treatment modality for MPM, we examined the antitumor effect of combination therapy consisting of pemetrexed chemotherapy and NPe6-PDT by comparing the antitumor effects of pemetrexed administered before or after NPe6-PDT in both in vitro and in vivo models.

\section{Materials and methods}

Cell cultures. The human mesothelioma cell lines, H28, H2452, MSTO-211H, and H2052 were purchased from the American Type Culture Collection (ATCC) (Manassas, VA, USA) $(24,25)$. These cell lines and human breast cancer MCF-7 cells transfected with human procaspase-3 cDNA (MCF-7c3 cells) were cultured in RPMI-1640 medium containing $10 \%$ fetal bovine serum (26).

Photosensitizer. NPe6 (Meiji Seika Pharma Co., Ltd., Tokyo, Japan) is a second-generation water-soluble photosensitizer with a molecular weight of 799.69 and a chlorine annulus; its highest absorption peak occurs at $407 \mathrm{~nm}$, while a second peak occurs at $664 \mathrm{~nm}(17,27)$.

Laser unit. A diode laser (Panasonic Healthcare Co., Ltd., Kanagawa, Japan) emitting continuous wave laser light at a wavelength of $664 \mathrm{~nm}$ was used as the light source for the excitation of NPe6 (28).

Measurement of the fluorescence intensity of NPe6 in the cells. MSTO-211H cells were exposed to pemetrexed at an $\mathrm{IC}_{50}$ dose of $1.2 \mu \mathrm{M}$ for $48 \mathrm{~h}$, and then were exposed to NPe6 $(15 \mu \mathrm{g} / \mathrm{ml})$ for $4 \mathrm{~h}$. The cells were washed with phosphate buffered saline (PBS). The NPe6 remaining in the cells was excited at $405 \mathrm{~nm}$, and the fluorescence was detected with a charged coupled device (CCD) camera system (Argus/HiSCa; Hamamatsu Photonics Co. Ltd., Shizuoka, Japan) through a multilaminate interference filter capable of selecting a fluorescence wavelength of $630 \mathrm{~nm}$, as previously reported (29).

Determination of cell viability. We evaluated the growth inhibitory effects using the tetrazolium salt WST-1 assay according to the manufacturer's instructions, as described previously $(29,30)$. The effects of four different treatment schedules were examined. For the treatment of PDT alone, cells were seeded into 96-well microculture plates at a density of $1 \times 10^{4}$ cells/well and allowed to adhere to the dish overnight. NPe6 was then added to the medium in increasing concentrations, followed by incubation at $37^{\circ} \mathrm{C}$ in the dark for $24 \mathrm{~h}$. The cells were washed with PBS and the medium was replaced; the cells were then irradiated with a laser $\left(33 \mathrm{~mW} / \mathrm{cm}^{2}\right.$; total energy, $10 \mathrm{~J} / \mathrm{cm}^{2}$ ) and cell viability was measured $72 \mathrm{~h}$ later. For the treatment of PDT followed by pemetrexed, the cells were incubated with NPe6 $(10 \mu \mathrm{g} / \mathrm{ml})$ for $24 \mathrm{~h}$. Then, the cells were treated by PDT and the medium was replaced with a medium containing pemetrexed, followed by culturing for $48 \mathrm{~h}$. For the treatment of pemetrexed alone, the cells were incubated with pemetrexed for $48 \mathrm{~h}$. For the treatment of pemetrexed followed by PDT, the cells were incubated with pemetrexed; $24 \mathrm{~h}$ later, NPe6 $(10 \mu \mathrm{g} / \mathrm{ml})$ was added. Forty-eight hours later, the cells were treated by PDT then incubated for $24 \mathrm{~h}$. For each protocol, the cell viability was measured at $72 \mathrm{~h}$ after the start of the treatment. Independent experiments were repeated at least three times to confirm the data.

Nude mice. Five-week-old BALB/c nude mice weighing 20-30 g were obtained from the Charles River Laboratories International, Inc. (L'Abresele, France). The animal experiments were conducted in accordance with the guidelines of the Animal Ethics Committee of Tokyo Medical University, complying with the Guidelines for the Welfare and Use of Animals in Cancer Research (31).

Protocol and therapeutic procedures. MSTO-211H cells were washed twice in Hank's solution (Invitrogen Life Technologies, Carlsbad, CA, USA), and $10^{7}$ cells were injected subcutaneously into the right thigh of individual nude mice. Treatments were initiated 7 days after tumor cell implantation, when the MSTO-211H tumors were $\sim 200 \mathrm{~mm}^{3}$ in volume. The tumor volumes were calculated using the following formula: tumor volume $=\mathrm{LD}^{2} / 2$ ( $\mathrm{L}$, long diameter; D, short diameter) (32). For the pemetrexed followed by PDT treatment, mice were intraperitoneally injected with pemetrexed (150 mg/kg daily) on days 7-11; on day 12 , the mice were intravenously injected with NPe6 $(10 \mathrm{mg} / \mathrm{kg})$ and irradiated with a $664-\mathrm{nm}$ laser $\left(100 \mathrm{~J} / \mathrm{cm}^{2}\right) 2 \mathrm{~h}$ later. The irradiation time was $16 \mathrm{~min}$ and $40 \mathrm{sec}$. For the PDT followed by pemetrexed treatment, mice were intravenously injected with NPe6 $(10 \mathrm{mg} / \mathrm{kg})$ and $2 \mathrm{~h}$ later irradiated with a 664-nm laser $\left(100 \mathrm{~J} / \mathrm{cm}^{2}\right)$ on day 7 ; on days $8-12$, the mice were intraperitoneally injected with pemetrexed $(150 \mathrm{mg} / \mathrm{kg}$ daily). The progress of each tumor was measured every day until day 28 , and the ratio of the tumor volume was calculated by comparing the volume with the tumor volume on day 7. All the in vivo studies were performed in accordance with the Guidelines for the Welfare and Use of Animals in Cancer Research (31).

Immunohistochemical analysis. Cells were grown on glass coverslips in $35-\mathrm{mm}$ petri dishes. To analyze the expression of TS, the coverslips were removed from the petri dishes, washed with PBS, and fixed in $1 \%$ formaldehyde for $30 \mathrm{~min}$. 

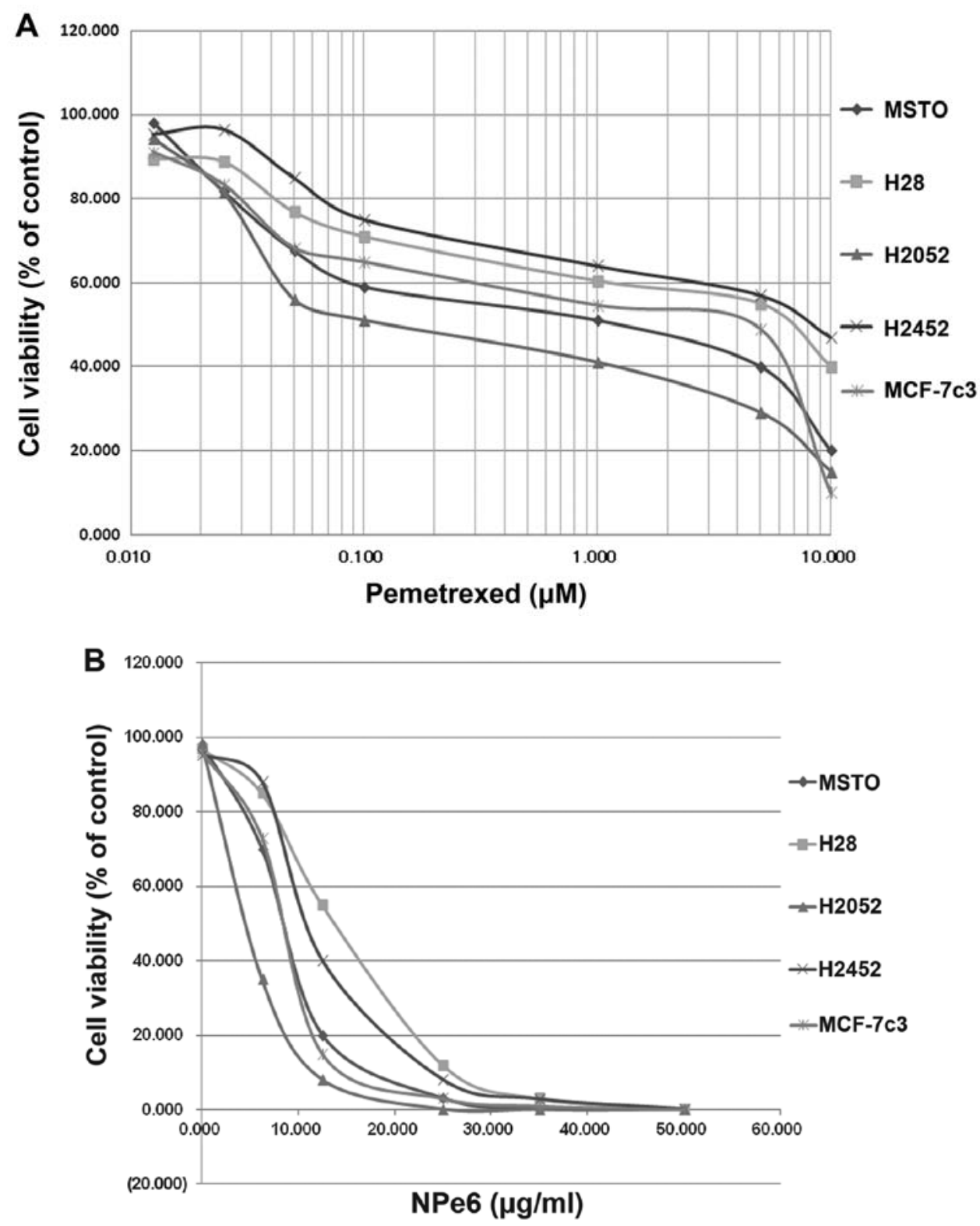

Figure 1. (A) Growth-inhibitory effect of pemetrexed in MSTO-211H (•), H28 (•), H2052 (४), H2452 (×), and MCF-7c3 cells (*). Cells were exposed to pemetrexed for $96 \mathrm{~h}$, and the growth-inhibitory effect was measured using the WST assay. (B) Growth-inhibitory effect of NPe6-PDT in MSTO-211H ( $\bullet$, H28 (•), H2052 (^), H2452 (×), and MCF-7c3 cells (*). Cells were exposed to NPe6 for $24 \mathrm{~h}$ and then washed with phosphate buffered saline (PBS); the medium was replaced. The cells were then irradiated with a diode laser $\left(33 \mathrm{~mW} / \mathrm{cm}^{2}, 10 \mathrm{~J} / \mathrm{cm}^{2}\right)$ and cultured for another $48 \mathrm{~h}$. The growth-inhibitory effect was measured using the WST assay.

After rinsing twice with PBS, the fixed cells were incubated in IFA buffer (PBS containing $1 \%$ bovine serum albumin, $0.1 \%$ Tween-20) for $10 \mathrm{~min}$ and then in IFA-containing mouse anti-TS antibody (clone 8F1; Zymed Laboratories, Inc., San Francisco, CA, USA) for $1 \mathrm{~h}$ at room temperature $(26,30,32)$.

The MSTO-211H tumors in BALB/c nude mice were collected before PDT and $24 \mathrm{~h}$ after PDT. We performed an immunohistochemical analysis of these samples using anti-TS antibody (clone 8F1; Zymed Laboratories, Inc.).

\section{Results}

NPe6-PDT alone, but not pemetrexed alone, exerts a strong antitumor effect against human malignant mesothelioma cell lines. We examined the antitumor effects of pemetrexed on MSTO-211H, NCI-H2052, NCI-H2452, and NCI-H28 using the WST assay (Fig. 1A). The $\mathrm{IC}_{50}$ values of pemetrexed were $1.2 \mu \mathrm{M}$ for MSTO-211H, $0.1 \mu \mathrm{M}$ for NCI-H2052, $10 \mu \mathrm{M}$ for NCI-H2452, and $8.4 \mu \mathrm{M}$ for NCI-H28; these values were similar to those in a previous report (25). In MCF-7c3, the $\mathrm{IC}_{50}$ value was $5.5 \mu \mathrm{M}$ (Fig. 1A). Unfortunately, treatment using pemetrexed alone was not sufficient to reach an $\mathrm{LD}_{90}$ in the NCI-H2452, and NCI-H28 cell lines, as previously reported (25). On the other hand, NPe6-PDT caused complete cell death in all four cell lines, and NPe6-PDT exerted a strong antitumor effect against MPM in vitro, with an $\mathrm{LD}_{90}$ being reached in all the cell lines (Fig. 1B). The $\mathrm{IC}_{50}$ values were $10 \mu \mathrm{g} / \mathrm{ml}$ of NPe6 and $10 \mathrm{~J} / \mathrm{cm}^{2}, 33 \mathrm{~mW} / \mathrm{cm}^{2}$ of laser irradiation. 

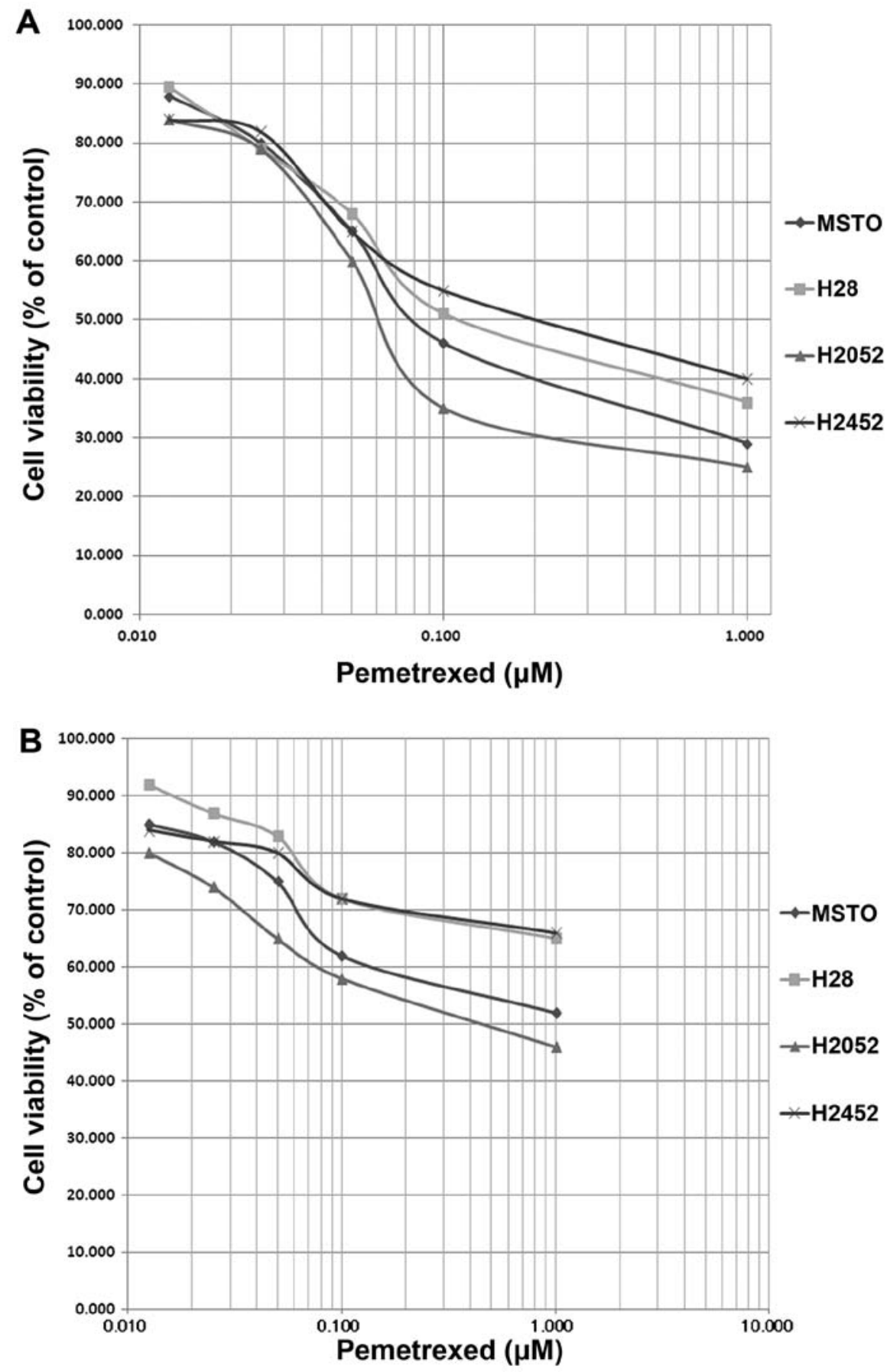

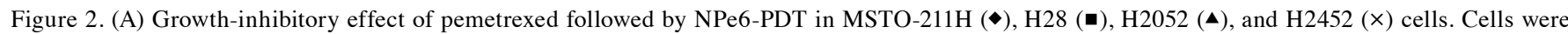
incubated with $1.2 \mu \mathrm{M}$ of pemetrexed, which is the $\mathrm{IC}_{50}$ dose for MSTO-211H cells; $24 \mathrm{~h}$ later, $10 \mu \mathrm{g} / \mathrm{ml}$ of NPe6 was added. Forty-eight hours after the start of treatment, the cells were irradiated with a diode laser $\left(33 \mathrm{~mW} / \mathrm{cm}^{2}, 10 \mathrm{~J} / \mathrm{cm}^{2}\right)$. These conditions for NPe6-PDT correspond to the IC $\mathrm{I}_{50}$ dose for MSTO-211H cells. At $72 \mathrm{~h}$ after the start of treatment, the growth-inhibitory effect was measured using the WST assay. (B) Growth-inhibitory effect of NPe6-PDT followed

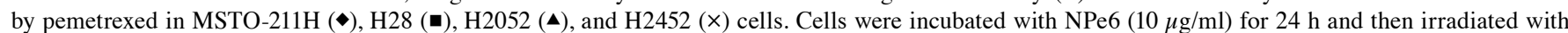
a diode laser $\left(33 \mathrm{~mW} / \mathrm{cm}^{2}, 10 \mathrm{~J} / \mathrm{cm}^{2}\right)$. These conditions for NPe6-PDT correspond to the $\mathrm{IC}_{50}$ dose for MSTO-211H cells. The cells were then washed with phosphate buffered saline (PBS), and the medium was replaced with a medium containing pemetrexed; the cells were then cultured for $48 \mathrm{~h}$. At $72 \mathrm{~h}$ after the start of treatment, the growth-inhibitory effect was measured using the WST assay.

Pemetrexed enhances the lethal effects of NPe6-PDT against MPM cell lines. We examined the effects of combination therapy using pemetrexed and NPe6-PDT. First, we evaluated whether pemetrexed pre-treatment enhanced the antitumor effect of NPe6-PDT in MPM cells. MPM cells were treated with pemetrexed for $48 \mathrm{~h}$ and then were washed with PBS three times; the cells were then incubated for $4 \mathrm{~h}$ with NPe6 $(10 \mu \mathrm{g} / \mathrm{ml})$. After incubation, the cells were irradiated with a diode laser $\left(664 \mathrm{~nm}, 10 \mathrm{~J} / \mathrm{cm}^{2}\right)$, which provided the $\mathrm{IC}_{50}$ dose of NPe6-PDT in MSTO-2511 cells. As shown in Fig. $2 \mathrm{~A}$, the $\mathrm{IC}_{50}$ values were $0.08 \mu \mathrm{M}$ for the MSTO-211H cells, $0.14 \mu \mathrm{M}$ for the $\mathrm{H} 28$ cells, $0.23 \mu \mathrm{M}$ for the $\mathrm{H} 2452$ cells, and $0.06 \mu \mathrm{M}$ for the $\mathrm{H} 2052$ cells. Thus, pemetrexed treatment followed by NPe6-PDT caused an initial decrease in 


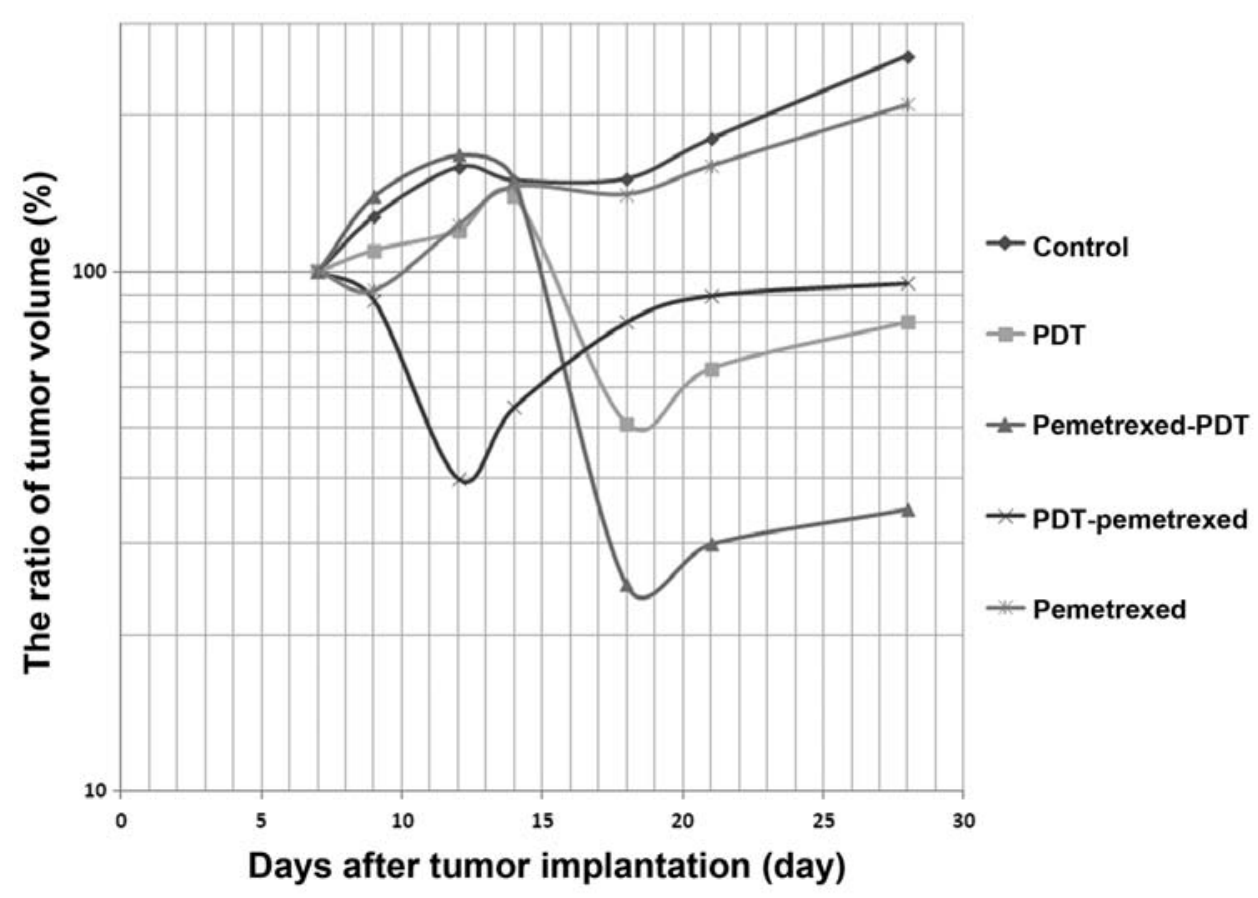

Figure 3. Nude mice transplanted with MSTO-211H tumors measuring 5-7 $\mathrm{mm}$ in diameter were treated by pemetrexed and/or NPe6-PDT. The tumor volumes were calculated using the following formula: tumor volume $=\mathrm{LD}^{2} / 2$ (L, long diameter; $\mathrm{D}$, short diameter). Untreated MSTO-211H tumors as control $(\bullet, \mathrm{N}=10)$, treated by NPe6-PDT alone $(\bullet, \mathrm{N}=10)$, treated by pemetrexed followed by photodynamic therapy (PDT) $(\boldsymbol{\bullet}, \mathrm{N}=10)$, treated by PDT followed by pemetrexed $(\times, \mathrm{N}=10)$, treated by pemetrexed alone $(*, \mathrm{~N}=10)$. For the pemetrexed followed by PDT treatment $(\mathbf{\Lambda})$, mice were intraperitoneally injected with pemetrexed $(150 \mathrm{mg} / \mathrm{kg}$ daily) on days 7-11; on day 12 , the mice were intravenously injected with NPe6 $(10 \mathrm{mg} / \mathrm{kg})$ and then irradiated with a $664-\mathrm{nm}$ laser $\left(100 \mathrm{~J} / \mathrm{cm}^{2}\right) 2 \mathrm{~h}$ later. The laser spot size was $14 \mathrm{~mm}$ in diameter, and the power output at the fiber tip was $154 \mathrm{~mW}$. The irradiation time was $16 \mathrm{~min}$ and 40 sec. For the PDT followed by pemetrexed treatment $(\times)$, mice were intravenously injected with NPe6 $(10 \mathrm{mg} / \mathrm{kg})$ and then $2 \mathrm{~h}$ later irradiated with a $664-\mathrm{nm}$ laser $\left(100 \mathrm{~J} / \mathrm{cm}^{2}\right)$ on day 7 ; on days $8-12$, the mice were intraperitoneally injected with pemetrexed (150 mg/kg daily). Tumor response was monitored until day 28 , and the ratio of the tumor volume was calculated by comparing the volume with tumor volume on day 7.

viability, indicating that pemetrexed enhances the lethal effect of NPe6 (Fig. 2A).

NPe6-PDT followed by pemetrexed treatment yielded no enhancement. We next examined whether NPe6-PDT followed by pemetrexed treatment enhanced the antitumor effect. First, MPM cells were treated with NPe6-PDT using the $\mathrm{IC}_{50}$ conditions (NPe6, $10 \mu \mathrm{g} / \mathrm{ml}$; laser irradiation, $10 \mathrm{~J} / \mathrm{cm}^{2}$ ). Then, the cells were treated with pemetrexed for $48 \mathrm{~h}$. The survival curves indicated that NPe6-PDT followed by pemetrexed treatment was incapable of obtaining an $\mathrm{IC}_{50}$ response except in the $\mathrm{H} 2052$ cells, and no enhancement of the treatment effects was observed (Fig. 2B).

Pemetrexed treatment enhanced the antitumor effect of NPe6-PDT against MPM tumors in vivo. We examined the efficacy of combination therapy with NPe6-PDT and chemotherapy using pemetrexed for MPM tumors. We transplanted MSTO-211H cells into nude mice as described in previous reports (33), and then treated the mice with pemetrexed for 5 days. On the sixth day of treatment, we treated the tumors with NPe6-PDT using $10 \mathrm{mg} / \mathrm{kg}$ of NPe6 and $10 \mathrm{~J} / \mathrm{cm}^{2}$ of laser irradiation. Fig. 3 shows that pemetrexed pre-treatment followed by NPe6-PDT enabled an 80\% loss in the tumor volume and inhibited the re-growth of the tumors. Using this dosage, NPe6-PDT alone decreased the tumor volume by $50 \%$; however, the tumor volume increased once again, reaching the pre-treatment value 10 days after PDT (Fig. 3).
We also evaluated the efficacy of NPe6-PDT followed by pemetrexed treatment, but this treatment schedule did not inhibit the re-growth of the tumor (Fig. 3). NPe6-PDT followed by pemetrexed treatment yielded no enhancement in tumor cell lethality in the in vivo experiments, similar to the results in vitro (Fig. 3).

Pemetrexed did not stimulate the accumulation of intracellular NPe6 in MSTO-211 cells. To examine the mechanism responsible for the enhancement in cell lethality enabled by pemetrexed pre-treatment followed by NPe6-PDT, we investigated whether pemetrexed stimulates the intracellular accumulation of NPe6 in MSTO-211 cells. MSTO-211 cells were pre-treated for $48 \mathrm{~h}$ with an $\mathrm{IC}_{50}$ dose of $1.2 \mu \mathrm{M}$, then exposed to NPe6 for $3 \mathrm{~h}$. The resulting accumulation of NPe6 was assessed by detecting red fluorescence using fluorescent microscopy (29). No significant difference in the intracellular accumulation of NPe6 was observed between a group with pemetrexed pre-treatment and one without the pre-treatment. Thus, pemetrexed pre-treatment did not enhance the accumulation of intracellular NPe6.

NPe6-PDT induced the expression of TS. The inhibition of TS, resulting in a decrease in thymidine available for DNA synthesis, is reportedly the primary mechanism of pemetrexed $(34,35)$. Therefore, we hypothesized that TS expression may affect the efficacy of combination therapy with pemetrexed and NPe6-PDT. We examined TS protein expression in the MPM cell lines using 

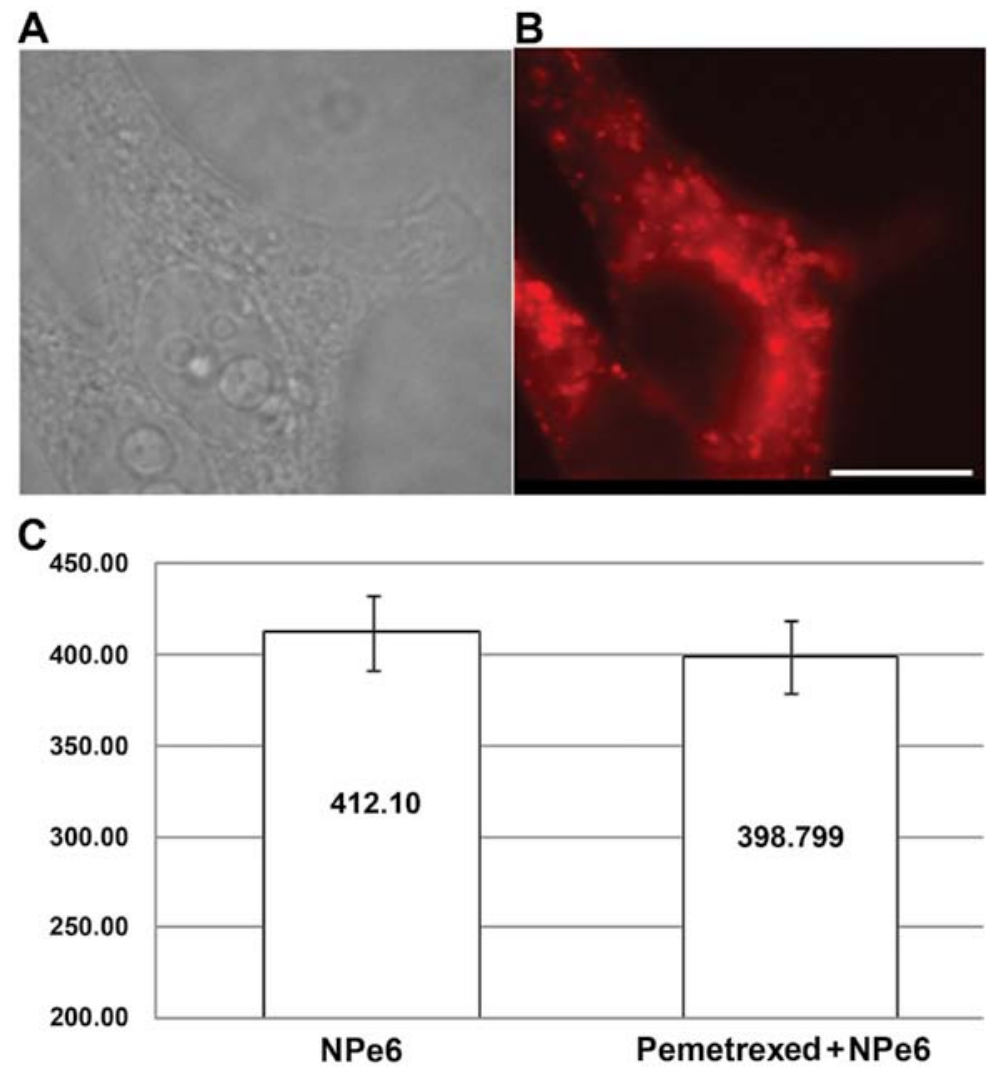

Figure 4. Localization of NPe6 in MSTO-211H cells and fluorescent intensity. Cells were exposed to pemetrexed at the $\mathrm{IC}_{50}$ dose of $1.2 \mu \mathrm{M}$ for $48 \mathrm{~h}$ and then were exposed to NPe6 $(15 \mu \mathrm{g} / \mathrm{ml})$ for $4 \mathrm{~h}$; the cells were then washed with phosphate buffered saline (PBS). (A) Image of the cells using white light. (B) The NPe6 in the cells was excited at $405 \mathrm{~nm}$, and red fluorescence was detected using a charged coupled device (CCD) camera system. Scale bar, $5 \mu \mathrm{m}$. (C) Fluorescence intensity of NPe6 in cells with or without pemetrexed pre-treatment. The fluorescence intensity of 10 cells was counted, and the average intensity per cell is shown. No and those without pemetrexed pre-treatment.
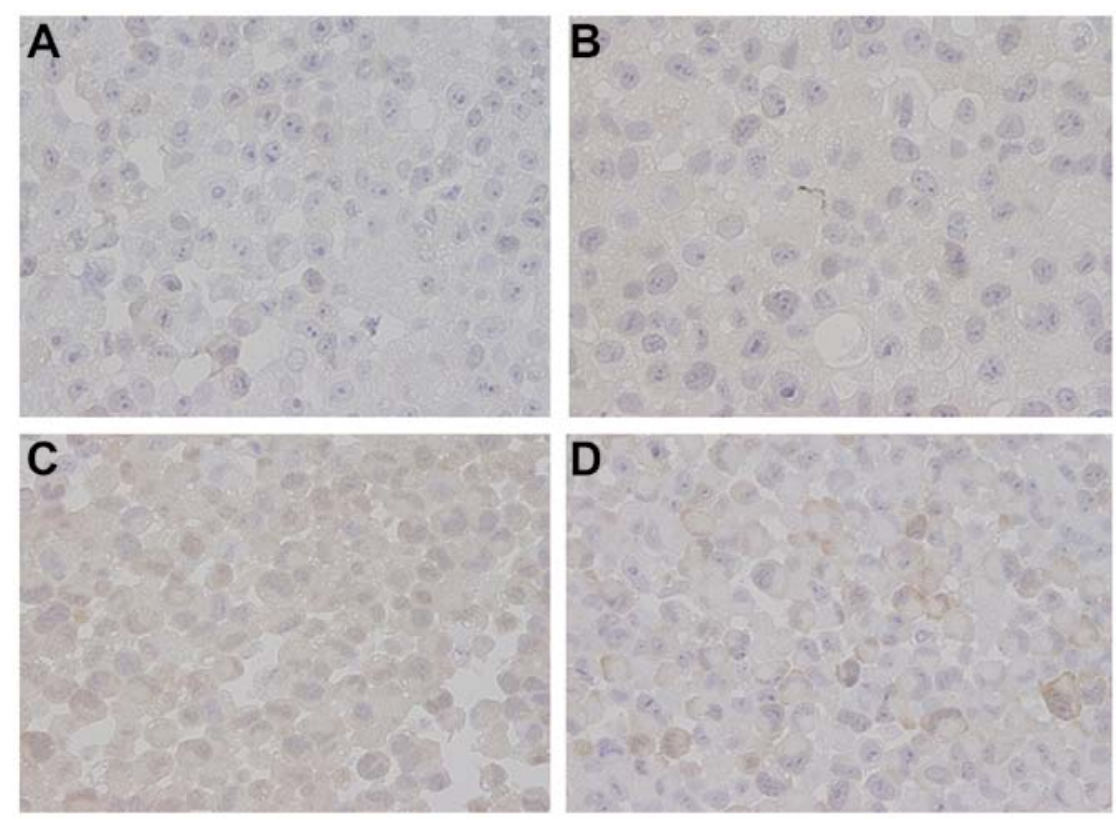

Figure 5. Immunohistochemical staining of human malignant pleural mesothelioma (MPM) cell lines. Immunohistochemical staining using anti-TS antibody (clone 8F1) in (A) MSTO-211H, (B) H2052, (C) H2452, and (D) H29 cells.

an immunohistochemical analysis (Fig. 5). The expression of TS was relatively low in MSTO-211H and NCI-H2052 cells but was relatively high in NCI-H2452 and NCI-H28 cells (Fig. 4).
In the in vivo model, NPe6-PDT induced TS expression in the MSTO-211H tumors $24 \mathrm{~h}$ after the laser irradiation (Fig. 5). These results suggest that the overexpression of TS protein 

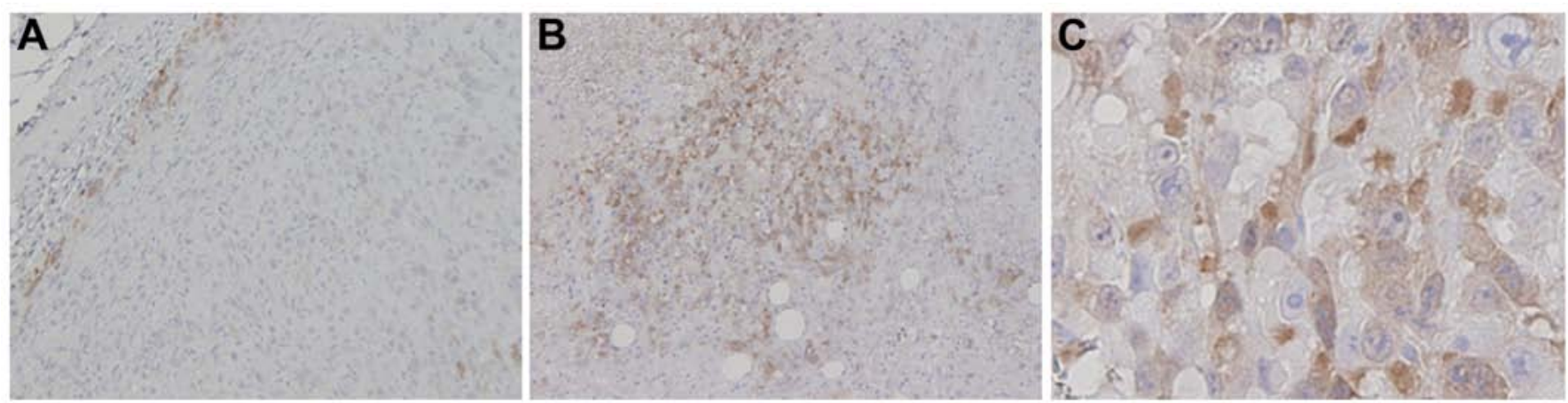

Figure 6. Immunohistochemical staining of MSTO-211H tumors. The MSTO-211H tumors in BALB/c nude mice were collected (A) before photodynamic therapy (PDT) and (B and C) $24 \mathrm{~h}$ after PDT. Immunohistochemical staining was performed using anti-TS antibody [magnification in (A) x10; (B) x10; (C) $\mathrm{x} 40]$.

induced by NPe6-PDT may be associated with the failure of pemetrexed to exert a tumoricidal action. Therefore, we concluded that NPe6-PDT followed by pemetrexed treatment did not enhance tumor cell lethality in the in vivo model.

\section{Discussion}

Recently, Debefve et al reported that PDT affects vascular barrier function and thus increases vessel permeability; this phenomenon may be exploited to facilitate targeted drug delivery (36). Snyder et al also reported that a direct vascular effect of PDT at relatively low light doses may be exploited to increase the uptake of systemically circulating drugs to tumors, and this new treatment concept has been named 'photodynamic drug delivery' (37). They developed a novel PDT treatment that enhances the delivery and efficacy of macromolecule-based cancer therapy, such as a liposomally encapsulated formulation of doxorubicin (37). Low-dose PDT reportedly increases microvessel permeability, thereby promoting the controlled release of circulating drugs into tissues; PDT additionally stimulates leukocyte-endothelial cell interactions, mediating the effects of PDT on improved drug delivery (38). Therefore, we hypothesized that NPe6-PDT may enhance the delivery of pemetrexed to the tumors and suspected that NPe6-PDT followed by pemetrexed treatment could provide a synergistic or additive effect in vivo. However, NPe6-PDT followed by pemetrexed did not enhance tumor cell lethality, compared with NPe6-PDT alone, either in vitro (Fig. 2B) or in vivo (Fig. 3). These results indicated that NPe6-PDT could not enhance the antitumor activity of pemetrexed and in fact produced some resistance to treatment, compared with PDT alone.

Pemetrexed reportedly inhibits multiple enzymes in the folate metabolic pathway, with TS being the main target. In NSCLC cell lines, high baseline TS expression levels confer resistance to pemetrexed, and the TS level is correlated with pemetrexed efficacy in a variety of solid tumors. As shown in Fig. 5, the expression of TS was relatively low in MSTO-211 and H2052 cells, which were somewhat more sensitive to pemetrexed than the $\mathrm{H} 2452$ and $\mathrm{H} 28$ cells (as shown in Fig. 1A). Based on our data shown in Fig. 1A regarding the growth inhibitory effects of pemetrexed, the H2052 cells were the most sensitive to pemetrexed of all the cell lines examined, as in a previous report, because the TS level was relatively low in the H2052 cells, compared with in the $\mathrm{H} 2454$ and $\mathrm{H} 28$ cells (25). As shown in Fig. 6, NPe6-PDT at the $\mathrm{IC}_{50}$ dose induced the expression of TS in MSTO-211 cells. Therefore, based on these results, we concluded that NPe6-PDT followed by pemetrexed treatment did not enhance tumor cell lethality possibly because of the NPe6-PDT-induced expression of TS. Moreover, we previously reported that NPe6-PDT can damage the microvasculature around tumors and induce a vascular shut-down effect, decreasing blood flow to the tumors (17). Sitnik et al also reported that PDT-induced microvasculature damage is associated with a significant decrease in the blood flow and severe hypoxia in the tumor (39). We suggested that NPe6-PDT does not enhance the delivery of pemetrexed but may, in fact, obstruct the delivery of pemetrexed to tumors.

Oleinick et al reported that photosensitizer accumulation can influence cellular sensitivity to PDT (40). Robey et al reported that the expression of ATP-binding cassette (ABC) transport proteins, which render tumor cells resistant to chemotherapeutic drugs, decreases the accumulation of photosensitizers and causes resistance to PDT (41). We have also previously reported that BCRP, a member of the ABC transporter family, decreases the accumulation of Photofrin and may be a molecular determinant (29).

Anand et al reported that methotrexate (MTX) stimulated the accumulation of an intracellular photosensitizer, protoporphyrin IX, and enhanced the antitumor effect of PDT using 5-aminolaevulinic acid (ALA), but that ALA-PDT followed by MTX yielded no enhancement in tumor cell lethality $(42,43)$. In the present study, as shown in Fig. 4, pemetrexed pre-treatment did not enhance the accumulation of intracellular NPe6. Further study is needed to explain why the combination of pemetrexed pre-treatment and NPe6-PDT has an additive effect on NPe6-PDT cytotoxicity both in vitro and in vivo. In conclusion, combination therapy using pemetrexed followed by NPe6 can enhance the cytotoxic effect of NPe6 and has important clinical implications.

Pass et al reported that intraoperative PDT did not prolong the survival of patients with MPM (22). However, we recently reported that NPe6-PDT exerted a strong antitumor effect against cancer lesions (29). Therefore, combination treatment using pemetrexed followed by NPe6-PDT may become a new 
treatment modality, and further combination with surgery may reduce local recurrence and prolong the survival of patients with malignant mesothelioma.

\section{Acknowledgements}

This study was supported in part by a Grant-in-Aid for Scientific Research (C) from Japan Society for the Promotion of Science (JSPS) (to J.U.) (KAKENHI 21591826).

\section{References}

1. Peto J,Decarli A,La Vecchia C,Levi F and NegriE: The European mesothelioma epidemic. Br J Cancer 79: 666-672, 1999.

2. Price B: Analysis of current trends in United States mesothelioma incidence. Am J Epidemiol 145: 211-218, 1997.

3. Hodgson JT, McElvenny DM, Darnton AJ, Price MJ and Peto J: The expected burden of mesothelioma mortality in Great Britan from 2002 to 2050. Br J Cancer 92: 587-593, 2005.

4. McCormack V, Peto J, Byrnes G, Straif K and Boffetta P: Estimating the asbestos-related lung cancer burden from mesothelioma mortality. Br J Cancer 106: 575-584, 2012.

5. Van Ruth S, Bass P and Zoetmulder FA: Surgical treatment of malignant pleural mesothelioma: a review. Chest 123 : 551-561, 2003.

6. Treasure T, Lang-Lazdunski L, Waller D, Bliss JM, Tan C, Entwisle J, Snee M, O'Brien M, Thomas G, Senan S, O'Byrne K, Kilburn LS, Spicer J, Landau D, Edwards J, Coombes G, Darlison L, Peto J and for the MARS trialists: Extra-pleural pneumonectomy versus no extra-pleural pneumonectomy for patients with malignant pleural mesothelioma: clinical outcomes of the mesothelioma and radical surgery (MARS) randomized feasibility study. Lancet Oncol 12: 763-772, 2011.

7. Pass HI, Kranda K, Temeck BK, Feuerstein I and Steinberg SM: Surgically debulked malignant pleural mesothelioma: results and prognostic factors. Ann Surg Oncol 4: 215-222, 1997.

8. Krug LM, Pass HI, Rusch VW, Kindler HL, Sugarbaker DJ, Rosenzweig KE, Flores R, Friedberg JS, Pisters K, Monberg M, Obasaju CK and Vogelzang NJ: Multicenter phase II trial of neoadjuvant pemetrexed plus cisplatin followed by extrapleural pneumonectomy and radiation for malignant pleural mesothelioma. J Clin Oncol 27: 3007-3013, 2009.

9. Adjei AA: Pemetrexed (ALIMTA), a novel multitargeted antineoplastic agent. Clin Cancer Res 10: 4276s-4280s, 2004.

10. Vogelzang NJ, Porta C and Mutti L: New agents in the management of advanced mesothelioma. Semin Oncol 32: $336-350,2005$

11. Vogelzang NJ, Rusthoven JJ, Symanowski J, Denham C, Kaukel E, Ruffie P, Gatzemeier U, Boyer M, Emri S, Maneqold C, Niyikiza C and Paoletti P: Phase III study of pemetrexed in combination with cisplatin versus cisplatin alone in patients with malignant pleural mesothelioma. J Clin Oncol 21: 2636-2644, 2003.

12. Rea F, Marulli G, Bortolotti L, Breda C, Favaretto AG, Loreggian L and Sartori F: Induction chemotherapy, extrapleural pneumonectomy (EPP) and adjuvant hemi-thoracic radiation in malignant pleural mesothelioma (MPM): Feasibility and results. Lung Cancer 57: 89-95, 2007.

13. Flores RM, Pass HI, Seshan VE, Dycoco J, Zakowski M, Carbone M, Bains MS and Rusch VW: Extrapleural pneumonectomy versus pleurectomy/decortication in the surgical management of malignant mesothelioma: results in 663 patients. J Thorac Cardiovasc Surg 135: 620-626, 2008.

14. Dougherty TJ, Gomer CJ, Henderson BW, et al: Photodynamic therapy. J Natl Cancer Inst 90: 889-905, 1998.

15. Dougherty TJ: An update on photodynamic therapy applications. J Clin Laser Med Surg 20: 3-7, 2002.

16. Edell ES and Cortese DA: Photodynamic therapy in the management of early superficial squamous cell carcinoma as an alternative to surgical resection. Chest 102: 1319-1322, 1992.

17. Kato H, Usuda J, Okunaka T, Furukawa K, Honda H, Sakaniwa N, Suga Y, Hirata T, Ohtani K, Inoue T, Maehara S, Kubota M, Yamada $\mathrm{K}$ and Tsuitsui $\mathrm{H}$ : Basic and clinical research on photodynamic therapy at Tokyo Medical University Hospital. Lasers Surg Med 38: 371-375, 2006.
18. Kennedy TC, McWilliams A, Edell E, Sutedja T, Downie G, Yung R, Gazdar A, Mahur PN; American College of Chest Physicians: Bronchial intraepithelial neoplasia/early central airways lung cancer: ACCP evidence-based clinical practice guidelines (2nd edition). Chest 132 (Suppl 3): S221-S233, 2007.

19. Krueger T, Altermatt HJ, Mettler D, Scholl B, Magnusson L and Ris HB: Experimental photodynamic therapy for malignant pleural mesothelioma with pegylated mTHPC. Laser Surg Med 32: 61-68, 2003.

20. Friedberg JS, Mick R, Stevenson J, Metz J, Zhu T, Buyske J, Sterman DH, Pass HI, Glatstein E and Hahn SM: A phase I study of Foscan-mediated photodynamic therapy and surgery in patients with mesothelioma. Ann Thorac Surg 75: 952-959, 2003.

21. Ris HB: Photodynamic therapy as an adjunct to surgery for malignant pleural mesothelioma. Lung Cancer 49 (Suppl 1): S65-S68, 2005.

22. Pass HI, Temeck BK, Kranda K, Thomas G, Russo A, Smith P, Friauf $\mathrm{W}$ and Steinberg SM: Phase III randomized trial of surgery with or without intraoperative photodynamic therapy and postoperative immunochemotherapy for malignant pleural mesothelioma. Ann Surg Oncol 4: 628-633, 1997.

23. Usuda J, Ichinose S, Ishizumi T, Hayashi H, Ohtani K, Maehara S, Ono S, Honda H, Kajiwara N, Uchida O, Tsutsui H, Ohira T, Kato $\mathrm{H}$ and Ikeda N: Outcome of photodynamic therapy using $\mathrm{NPe} 6$ for bronchogenic carcinomas in central airways $>1.0 \mathrm{~cm}$ in diameter. Clin Cancer Res 16: 2198-2204, 2010.

24. Ozasa H, Oguri T, Uemura T, Miyazaki M, Maeno K, Sato S and Ueda R: Significance of thymidylate synthase for resistance to pemetrexed in lung cancer. Cancer Sci 101: 161-166, 2010.

25. O'Kane SL, Eagle GL, Greenman J, Lind MJ and Gawkwell L: COX-2 specific inhibitors enhance the cytotoxic effects of pemetrexed in mesothelioma cell lines. Lung Cancer 67: 160-165, 2010.

26. Usuda J, Chiu SM, Murphy ES, Lam M, Nieminen AL and Oleinick NL: Domain-dependent photodamage to Bcl-2. A membrane anchorage region is needed to form the target of phthalocyanine photosensitization. J Biol Chem 278: 2021-2029, 2003.

27. Usuda J, Hirata T, Ichinose S, Ishizumi T, Inoue T, Ohtani K, Maehara S, Yamada M, Tsutsui H, Okunaka T, Kato H and Ikeda N: Tailor-made approach to photodynamic therapy in the treatment of cancer based on Bcl-2 photodamage. Int J Oncol 33: 689-696, 2008.

28. Kato H, Furukawa K, Sato M, Okunaka T, Kusunoki Y, Kawahara M, et al: Phase II clinical study of photodynamic therapy using mono-L-aspartyl chlorine e6 and diode laser for early superficial squamous cell carcinoma of the lung. Lung Cancer 42: 103-111, 2003.

29. Usuda J, Tsunoda Y, Ichinose $S$, Ishizumi T, Ohtani K, Maehara S, Ono S, Tsutsui H,Ohira T, Okunaka T, Furukawa K, Sugimoto Y, Kato $\mathrm{H}$ and Ikeda N: Breast cancer resistant protein (BCRP) is a molecular determinant of the outcome of photodynamic therapy (PDT) for centrally located early lung cancer. Lung Cancer 67: 198-204, 2010.

30. Xue LY, Chiu SM and Oleinick NL: Photodynamic therapy-induced death of MCF-7 human breast cancer cells: a role for caspase-3 in the late steps of apoptosis but not for the critical lethal event. Exp Cell Res 263: 145-155, 2001.

31. Workman P, Aboagye EO, Balkwill F, Balmain A, Bruder G, Chaplin DJ, Double JA, Everitt J, Farningham DA, Glennie MJ, Kelland LR, Robinson V, Stratford IJ, Tozer GM, Watson S, Wedge SR, Eccles SA; Committee of the National Cancer Research Institute: Guidelines for the welfare and use of animals in cancer research. Br J Cancer 102: 1555-1577, 2010.

32. Ohtani K, Usuda J, Ichinose S, Ishizumi T, Hirata T, et al: High expression of GADD-45 $\alpha$ and VEGF induced tumor recurrence via upregulation of IL-2 after photodynamic therapy using NPe6. Int J Oncol 32: 397-403, 2008.

33. Van TT, Hanibuchi M, Kakiuchi S, Sato S, Kuramoto T, Goto H, Mitsuhashi A, Nishioka Y, Akiyama S and Sone S: The therapeutic efficacy of S-1 against orthotopically implanted human pleural mesothelioma cells in severe combined immunodeficient mice. Cancer Chemother Pharmacol 68: 497-504, 2011.

34. Cappia S, Righi L, Mirabelli D, Ceppi P, Bacillo E, Ardissone F, Molinaro L, Scagliotti GV and Papotti M: Prognostic role of osteopontin expression in malignant pleural mesothelioma. Am J Clin Pathol 130: 58-64, 2008. 
35. Righi L, Papotti MG, Ceppi P, Bille A, Bacillo E, Molinaro L, Ruffini E, Scagliotti GV and Selvaggi G: Thymidylate synthase but not excision repair cross-complementation group 1 tumor expression predicts outcome in patients with malignant pleural mesothelioma treated with pemetrexed-based chemotherapy. J Clin Oncol 28: 1534-1539, 2010.

36. Debefve E, Mithieux F, Perentes JY, Wang Y, Cheng C, Schaefer SC, Ruffieux C, Ballini JP, Gonzalez M, van den Bergh H, Ris HB, Lehr HA and Krueger T: Leukocyte-endothelial cell interaction is necessary for photodynamic therapy induced vascular permeabilization. Lasers Surg Med 43: 696-704, 2011

37. Snyder JW, Greco WR, Bellnier DA, Vaughan L and Henderson BW: Photodynamic therapy: a means to enhanced drug delivery to tumors. Cancer Res 63: 8126-8131, 2003.

38. Wang Y, Perentes JY, Schäfer SC, Gonzalez M, Debefve E, Lehr HA, van den Bergh $\mathrm{H}$ and Krueger T: Photodynamic drug delivery enhancement in tumors does not depend on leukocyte-endothelial interaction in a human mesothelioma xenograft model. Eur J Cardiothorac Surg 42: 348-354, 2012.
39. Sitnik TM, Hampton JA and Henderson BW: Reduction of tumor oxygenation during and after photodynamic therapy in vivo: effects of fluence rate. Br J Cancer 77: 1386-1394, 1998.

40. Oleinick NL, Morris RL and Belichenko I: The role of apoptosis in response to photodynamic therapy: what, where, why, and how. Photochem photobiol Sci 1: 1-21, 2002.

41. Robey RW,Steadman K, PolgarO and Bates SE: ABCG2-mediated transport of photosensitizers: potential impact on photodynamic therapy. Cancer Biol Ther 4: 187-194, 2005.

42. Anand S, Honari G, Hasan T, Elson P and Maytin EV: Low-dose methotrexate enhances aminolevulinate-based photodynamic therapy in skin carcinoma cells in vitro and in vivo. Clin Cancer Res 15: 3333-3343, 2009.

43. Sinha AK, Anand S, Ortel BJ, Chang Y, Mai Z, Hasan T and Maytin EV: Methotrexate used in combination with aminolaevulinic acid for photodynamic killing of prostate cancer cells. Br J Cancer 95: 485-495, 2006. 